\begin{tabular}{rr} 
çağdaş & Yaratıcı Drama Dergisi 2015, 10(1), 103-116 \\
drama & www.yader.org \\
\hline
\end{tabular}

\title{
İnternet Bağımlılığı ve Süreçsel Drama: Bir Bağımlılığın Önlenebilir Gelişimi*
}

\author{
Hakan Sezerel ${ }^{1}$ \\ Ö. Özlem Gökbulut ${ }^{2}$
}

\begin{tabular}{|c|c|}
\hline Makale Bilgisi & $\ddot{\mathrm{O} z}$ \\
\hline DOI: $10.21612 /$ yader.2015.010 & \multirow{8}{*}{$\begin{array}{l}\text { Bu çalışmada, süreçsel drama yaklaşımından yararlanılmıştır. Süreçsel dramanın } \\
\text { temel özellikleri göz önünde tutularak, katılımcılar için ögrenme alanının (internet } \\
\text { bağımlılığı) bir amaç içinde ele alınması gerekliliği benimsenmiştir. Ayrıca } \\
\text { uzman mantosu yaklaşımı içinde, bir işletme kurulmuşs (danışmanlık hizmeti veren } \\
\text { bir kurum), katılımcılardan bağımsız bir müşteri kurgulanmış (çocuğu internet } \\
\text { bağımlısı olan ve bir bağımlılıkla mücadele merkezi kurmak isteyen bir anne) ve } \\
\text { çalışanlara (katılımcılar) yer verilmiştir. Katılımcılar, çalışanlar olarak bir problem } \\
\text { tanımlamakta, diğer bir deyişle internet bağımlılığı konusunu nesneleştirmektedir. } \\
\text { Süreçsel drama yaklaşımının bir diğer katkısı da katılımcılarda, kısa sürede "biz” } \\
\text { duygusunu oluşturmasıdır. Katılımcılar ve lider, birlikte, hayali bir görevi yerine } \\
\text { getirebilmek için çeşitli rolleri denemekte ve bir araştırma sürecini işletmektedir. } \\
\text { Oturumlar boyunca, süreçsel drama yaklaşımı temelinde, ilgili yöntem ve teknikler } \\
\text { sentezlenmeye çalışılarak, internet bağımlısı olan bir çocuğun annesine yardım } \\
\text { süreci kanalıyla, katılımcıların ilgileri örgütlenmeye çalışılmıştır. }\end{array}$} \\
\hline \multirow{8}{*}{$\begin{array}{l}\text { Anahtar Sözcükler } \\
\text { Yaratıcı drama } \\
\text { Süreçsel drama } \\
\text { Uzman mantosu } \\
\text { Internet bağımlılığl }\end{array}$} & \\
\hline & \\
\hline & \\
\hline & \\
\hline & \\
\hline & \\
\hline & \\
\hline & $\begin{array}{l}\text { Çalışmayı değerlendirmek için kullanılan veri toplama araçları; katılımcıların } \\
\text { drama çalışmaları öncesinde internet bağımlılığına ilişkin bilgilerini yoklamak } \\
\text { amacıyla açık uçlu sorulardan oluşan bir ön test, çalışmanın sonunda da aynı } \\
\text { soruların sorulduğu bir son test uygulanmış ve aradaki fark olup olmadığına } \\
\text { bakılmıştır. Ayrıca katılımcıların çalışma boyunca ürettikleri mektup, gazete, } \\
\text { afışler, çalışma değerlendirme yazıları gibi materyaller incelenerek içerik analizi } \\
\text { yapılmıştır. Çalışmada, internet bağımlılığının nedenleri, oluşumu, etkileri ve } \\
\text { mücadele yöntemleri üzerine katılımcıların bilgi ve yaşantılarının ilerletilmesine } \\
\text { çalışılmıştır. Gerek katılımcıların ifadeleri ve yarattıkları ürünler, gerekse liderin } \\
\text { gözlemleri bu konuda bir başarı sağlandığını göstermektedir. }\end{array}$ \\
\hline
\end{tabular}

\section{Internet Addiction and Process Drama: The Resistible Rise of An Addiction}

\begin{tabular}{|c|c|}
\hline Article Info & Abstract \\
\hline DOI: $10.21612 /$ yader.2015.010 & The aim of this study was to determine views of geography teacher candidates \\
\hline $\begin{array}{l}\text { Keywords } \\
\text { Creative drama } \\
\text { Process drama } \\
\text { Mantle of expert } \\
\text { Internet addiction }\end{array}$ & $\begin{array}{l}\text { on creative drama. To this end, } 73 \text { teacher candidates of KTU Fatih Faculty of } \\
\text { Education, Geography Education Program took part as the reserach group. The } \\
\text { research was held during the 'Teachig Methods'course that commenced 2014-2015 } \\
\text { fall semester. A lesson plan was enriched with creative drama and presented to the } \\
\text { research group. A qualitative approach was conducted to examine the opinions of } \\
\text { the teachers in this study. After the lesson conducted with creative drama, the }\end{array}$ \\
\hline
\end{tabular}

* Bu çalışma Çağdaş Drama Derneği Yaratıcı Drama Eğitmenliği/ Liderliği Programı Bitirme Projesi’nden üretilmiştir.

1 Yrd. Doç.Dr. Anadolu Üniversitesi, Turizm Fakültesi, Turizm İşletmeciliği Bölümü, Yunus Emre Kampüsü, Eskişehir, E-posta: hakansezerel@anadolu.edu.tr

2 Bilim Uzmanı, Milli Eğitim Bakanlığı, Ankara-Türkiye, e-posta: ooozlemgokbulut@gmail.com 
views of the teacher candidates were asked using semi-structured interview form. The results are modeled with NVivo 10 program which were subjected to content analysis. The opinions of teacher candidates were collected with semi-structured form which was followed by the content analysis. The result of the study is that the majority of the participants had not formarly taken creative drama education. Creative drama is also described by geography teacher candiates as effective, fun, creative, socializing.

\section{Giriş}

İnsanların bilgi teknolojileriyle kurdukları ilişkiler beklenmedik sonuçlar doğurmaktadır. ${ }^{3}$ Bu sonuçlardan biri de, yakın dönemde ortaya çıkan "internet bağımlılığı" olgusudur. Bu çalışmada, bilgi teknolojilerinin gelişimi ve internetle birlikte ortaya çıkan, internet bağımlılı̆̆ konusu incelenmektedir.

İnternet kullanımı 2013 yılı verilerine göre 7.181.858.619 kişiye ulaşmıştır (http://www. internetworldstats.com). Bu durum, 2000 y1lından bu yana kullanıcı sayısının neredeyse yediye katlandığını göstermektedir. Her sosyal olguda olduğu gibi, nicelikteki bu artış, niteliğe de etki ederek, sosyal yapı ve ilişkileri değiştirmekte ve internete ilişkin yeni toplumsal olayları ortaya çıkarmaktadır.

İlk kez 1960 yılında, Amerika'da bir grup araştırmacı tarafından askeri amaçlar için tasarlanan internet (o dönemdeki adıyla ARPANET); 1980'lerde hızla gelişerek, 1991 yılında worldwide web (www)'in icadı ve özellikle 1995 yılından itibaren artan kullanıcı sayısına bağlı olarak, dünyada en yaygın iletişim ortamı haline gelmiştir (Arısoy, 2009; Batıgün ve Kılıç, 2011; Shek ve Yu, 2012). O tarihten bu yana, cep telefonu, bilgisayargibi iletişim araçları aracılığıyla kullanılan internet, "geleneksel" olarak tanımlanan iletişim teknolojilerinin yerini almıştır. İletişim teknolojilerinin gelişimi bir yandan yaşamı kolaylaştırırken, (iletişim, ticaret, uzaktan eğitim, yeni sosyal ağlara katılım vb.); diğer yandan özellikle gençler için ( bedensel, psikolojik gelişim ve sosyal ilişkiler) çeşitli sorunları beraberinde getirmektedir (Cengizhan, 2005). Bir anlamda, sanal dünyanın "gerçek" dünyayı "istila" ettiği ve bu durumun sonuçlarından birinin de internet bağımlılığı olduğu düşünülmektedir (Şimşek ve Balaban-Sal1, 2014).

İnternet bağımlılığına yönelik araştırmalar Goldberg'in (1995) internet bağımlılığı kavramını tanımlamasıyla başlamıştır. İlgili yazında, bireylerin yeni nesil elektronik iletişim araçlarıyla kurdukları "norm" dışı davranışlar; bilgisayar bağımlılığı (Arısoy, 2009) veya internet bağımlılığ1 (Ayas vd., 2011) olarak tanımlanmaktadır. Diğer tanımlamalar ise, "aşırı internet kullanımı", "uygun olmayan internet kullanımı" biçiminde görülmektedir. Problemli internet kullanımı (problematic internet use/PIU) veya internet bağımlılığı rahatsızlığı (İnternet addictiondisorder/iad) kavramları, aşırı ya da kontrolsüz internet kullanımına bağlı olarak ortaya çıkan endişe ve sağlığın bozulmasına yol açan meşguliyet, dürtü ya da davranışları ifade etmek için kullanılmaktadır (Weinstein, 2014). Konuyu ilk kez görgül (ampirik) bir araştırmayla sınayan Young (1996) internet bağımlılığının kumar, alkol, uyuşturucu bağımlılıkları gibi bir bağımlılık türü olduğunu; akademik, sosyal ve mesleki zararlarını belirlemiştir. Daha sonra yapılan araştırmalarda internet bağımlılığının nedenleri, ortaya çıkışı ve kapsamı üzerinde yoğunlaşılmıştır. Bu çalışmada, benzer davranış ve durumları kapsamak için "internet bağımlılı̆̆ı" nitelemesi tercih edilmiştir.

4 Ebeveynlerin farklı nedenlerden dolayı, çocuklarına facebook ve like isimlerini verdikleri kaydediliyor (Hazar, 2011). 
Yazında, internet bağımlılığına ilişkin üç alt kategoriden söz edilmektedir. Bunlar: aşırı oyun- kumar oynama, siberseks benzeri seksüel meşguliyetler ile elektronik posta ve mesajları da içeren sosyalleşme ya da sosyal ağlar kurma etkinlikleridir. Üç başlıkta da ortak olan dört boyut sunulmaktadır: a) aşırı kullanım; zaman mefhumundan kopuş ve günlük işlerin bir kenara bırakılması, b) bilgisayara (internet sağlayan teknolojilere) ulaşım olmadığında kızgınlık, gerginlik, ve/veya depresyon duygularına yol açan yoksunluk belirtileri c) daha iyi teknolojilere, yazılıma ve daha uzun süre kullanıma duyulan istek, d) tartışmalar, yalan söyleme, düşük başarı, sosyal izolasyon ve tükenmişliğe neden olan yan etkilerdir(White, 2011). İnternet bağımlılı̆̆ konusundaki tartışmalar internet bağımlılığı semptomlarının başı başına mı ele alınması gerektiği, yoksa anksiyete, depresyon, dikkat bozukluğu ve dürtü kontrol bozukluğu gibi başka rahatsızlıkların bir ürünü olarak mı incelenmesi gerektiği yönünde sürmektedir.Diğer bir deyişle, konunun uzmanları arasında internet bağımlılığının kapsamı ve tanımlanması açılarından bir görüş birliğinden söz etmek olanaklı görünmemektedir.

İnternet kullanımı, hemen bütün toplumsal kategoriler için belirli riskleri barındırmakla birlikte, internet kullanımı konusunda en "kırılgan" kesimin öğrenciler olduğu düşünülmektedir. Çünkü akademik yetkinlik için her geçen gün daha çok internete bağlanan eğitim sistemi, bir bakıma öğrencilerin internet bağımlılığına "yakalanmasının" temel nedeni olmaktadır. Teknoloji yönelimli olan toplum, öğrencilerden teknolojik bilgi ve yeteneklerini geliştirmelerini talep etmekte, (Nalwa ve Anand, 2003) bu durum ise, internet bağımlılı̆̆ konusunda araştırmacıların ve eğitimcilerin daha fazla endişelenmesine neden olan "yan etkileri”" ortaya çıkarmaktadır.

Yukarıda belirtildiği gibi, internet bağımlılı̆̆ı yazını, diğer bağımlılıklara koşut olarak benzer kavramları kullanmaktadır. İnternet bağımlılığına yönelik yazın incelendiğinde, internet bağımlılığına ilişkin aşağıdaki bileşenlerin varlığından söz edilmektedir (Griffiths,2000, s. 211-212):

- Bağımlılığın görünür hale gelmesi: Bu durum, kişi için belirli bir etkinliğin en önemli etkinlik hale gelmesiyle oluşmaktadır. Buna göre, kişi, zihinsel ve davranışsal olarak bu etkinlikle meşgul olmakta, sürekli olarak söz konusu etkinliğe ulaşacağı ilk firsatı beklemektedir.

- Duygusal durumun değişmesi: Kişilerin, öznel bir deneyim olarak, belirli bir etkinliği (internet bağımlılığını) sorunlarla başa çıkmada bir kaçış noktası olarak görmelerini ifade etmektedir.

- Tölerans: Bir etkinliğin sonuçlarını arttırmak için miktarını arttırma durumudur. Örneğin, kumar bağımlılarının bahsin miktarını arttırmalarında hissettikleri coşku hissinin de artmasıdır.

- Yoksunluk semptomları: Bir etkinliğin gerçekleştirilememesi ya da birden sonlandırılması halinde yaşanan mutsuzluk halidir.

- Çatışma: Kişinin bağımlılık durumu yüzünden kendisi ve diğer kişilerle yaşadığı çatışma durumlarını ifade etmektedir.

- Tekrarlama: Önceki dönemde bağımlılık olarak tanımlanan davranış örüntülerinin tekrarlamasını ifade etmektedir.

İnternet bağımlılığı genel olarak, diğer bağımlılık türlerinden hareketle anlaşılmaya ve açıklanmaya çalışılan bir olgudur. Olgunun ortaya çıkışının görece yeni oluşu ve konu hakkında 
yapılan araştırmaların sınırlılığı göz önüne alındığında, ilgili yazında sınırları net olarak çizilmiş bir kapsamdan söz etmenin güç olduğu görülmektedir. Buna karşın, araştırmalar bağımlılığın nedenlerini üç temel değişken etrafında incelemektedir. Bunlar; internete bağlanma süresi, internete bağlanma nedeni ve kişilik özellikleri olmak üzere sınıflandırılmaktadır (Şimşek ve Balaban- Salı, 2014).

a) Internet kullanım süresi: Çoğu araştırma, internet bağımlılı̆̆ını yordamada internete bağlanma süresini bir değişken olarak kabul etmektedir. Zaman değişkeninin diğer bir yanı ise gece kullanımı ile gündüz kullanımı arasındaki farktır. Buna göre, gece daha uzun süre internete bağlanan kişilerin uykularından feragat etme vb. gibi nedenlerle daha bağımlılığa yatkın olduğunu görülmektedir (Ferraro vd., 2007). İnternet bağımlılığının internet kullanım süresiyle ilişkisinin diğer bir unsuru ise, ilgili teknolojiye yakın/sahip olup olmamaktır. İnternet kullanımı için gerekli teknolojiye sahip olan ya da yakın olan kişilerin, -özellikle gençlerin- zaman sınırlaması gibi bir etken olmadığında, internete bağlanma isteklerini gideriyor olmaları, bağımlılığın bir nedeni olarak görülmektedir (Çakır vd., 2011).

b) Internet kullanma nedeni: İnternet bağımlılı̆̆ına yatkınlık gösteren kimselerin boşluk duygusunu ve bireysel gereksinimlerini giderme konusunda düşük katlanma eşikleri olan kişiler olduğu düşünülmektedir. Bu özellikler; kişileri, interneti, anksiyete ve hayal kırıklığından kaçındıkları zihinsel bir sığınak olarak görme eğilimine itmektedir. Bu anlamda; internet, normal fiziksel olanakların ötesine geçerek, bilgi sağlamada çok çeşitli kaynak ulaşımını, dünya çapında sanal olarak insanlarla tanışmayı mekansal ve zamansal sınırların ötesine geçmeyi sağlamaktadır (Ferraro vd., 2007). Şimşek ve Balaban Salı (2014), Seligman'ın (2007) mutluluk üzerine geliştirdiği düşüncelerinden yola çıkarak, internet bağımlılı̆̆ını bireysel mutluluk arayışıyla ilişkilendirmektedir. $\mathrm{Bu}$ yaklaşımda, (otantik) mutluluk; haz, bağlanma ve anlamlı yaşam deneyimleri arasındaki dengeyle sağlanmaktadır. Bu üç bileşen gözden geçirildiğinde; hazzın, bağlanma ve anlamlı yaşam deneyimlerine göre mutluluğa daha az etki ettiği saptanmıştır. Mutluluk;güç ve değerlerin deneyimlenmesinden kaynaklanan bir durum olarak ortaya çıkmaktadır. Anlamlı tecrübeler ve akış (Csikszentmihalyi, 2005) yerine kişiler, mutluluğa ulaşmak için haz isteklerini tatmin etmeye çalışmaktadır. İnterneti kullanmanın nedenlerinden biri de, kişilerin kendilerini endişeli veya yalıtılmış/yalnız hissettiklerinde bu ruh halinden kurtulmak için internet kullanımına başvurmaları, bu durumun da fasit bir daire biçiminde bir kısırdöngüyle sonuçlanmasıdır (Balcı ve Gülnar, 2009). Çalışmalar, sosyal destek konusunun da internet kullanımıyla ilişkili olduğuna yönelik bulgular sunmaktadır. Çevrelerinden yeterli sosyal destek göremeyen kişilerin internet bağımlılığına daha yatkın oldukları ve sosyal desteğin eksikliğinin internete yönelmede bir değişken olduğu düşünülmektedir (Batıgün ve Kılıç, 2011).

Yazında internet bağımlığ bağlamında ele alınan diğer bir etmen ise, kişilik özellikleridir. Yapılan kuramsal ve görgül çalışmalar, bazı kişilik özelliklerinin internet bağımlılığına neden olabileceğini göstermektedir. İnternetin gün içerisinde uzun süreli ve iletişim amacıyla kullanımı, üst sosyoekonomik düzey, erkek olmak, gelecek beklentisi, yaşam doyumu ve özdenetimin düşük; nörotizm, anksiyete ve somatizasyonun (ruhsal problemleri bedene yansitma) ise yüksek olması internet bağımlılığını yordayan değişkenler olarak ortaya konmaktadır. Kişilikle ilgili özellikler için diğer bir katkı ise, yazındaki içedönüklük/dışadönüklük ayrımından gelmektedir. Dışa dönük kişilerin "gerçek" yaşamda sosyal etkileşimi içe dönüklere nazaran daha çabuk başlatacakları ve doğrudan iletişime geçmekten hoşlanacakları varsayılırken, içedönük kişiler için internet daha güvenli bir iletişim ortamı sağlamaktadır(Batıgün ve Kılıç, 2011). 
İnternet bağımlılı̆ğ kapsamında ele alınan davranışların; kişiye, aile yaşamına, arkadaşlık ilişkilerine çeşitli etkileri bulunmaktadır. İnternet bağımlılığının etkileri; davranışsal etkiler, fiziksel ve ruhsal etkiler ile sosyal etkiler olmak üzere üç grupta toplanmaktadır (Balcı ve Gülnar, 2009, s. 8). İnternet bağımlılığının etkilerinde öne çıkan unsurlar, genel olarak, internete ayrılan sürenin artış1, diğer etkinliklere ayrılan sürelerde de kontrol edilemeyen internete bağlanma arzusu, "gerçek" yaşamdaki sosyalleşmeden ziyade "sanal" sosyalleşmeyi yeğleme ve tüm bunlara bağlı olarak yaşam kalitesinin düşüşü olarak sıralanabilir. Bunların yanında kimi araştırmacılar, internet bağımlılığı ile depresyon arasında da bir ilişki olduğunu öne sürmektedir. Buna göre; depresyon, internet bağımlılığında hem bir neden, hem de bir sonuç özelliği göstermektedir. Başka sosyolojik ya da psikolojik etkenler nedeniyle depresyon halinde olan kişi, internete yönelip bağımlı olabileceği gibi, internet bağımlısı olduktan sonra da bağımlılığından dolayı depresyon rahatsızlığı gösterebilmektedir. (Günüç ve Kayri, 2010). İnternet bağımlılığının obsesif ve agresif davranışlara; şiddet eğilimine, öğrenme bozukluklarına, etkinlik ve hareket eksikliğine bağlı sağlık problemlerine, sosyal ilişkilerde gerilemeye, hayal ve gerçek arasında karmaşa yaşama (Ayas, 2011) gibi etkilere neden olduğu da kaydedilmektedir. Sağlıklı bir bireyin de, psikiyatrik ya da psikolojik rahatsızlıklar olmaksızın, mutsuzluğa bağlı olarak internet bağımlılığına yakalanabileceği öne sürülmektedir. Bu iddiaya göre, bireyler kendilerini mutlu etmek için, istenmedik miktarda ve aşırı biçimde internet kullanımına başvurmaktadır (Çardak, 2013).

İnternet bağımlılığı ile mücadeleye ilişkin müdahale ve stratejiler büyük oranda madde bağımlılı̆̆ına ilişkin tedavinin uyarlanması biçimde gerçekleşmektedir (Weinstein, 2014; Ekinci, 2002). İnternet bağımlılığının kanıtlara dayalı tedavisi için önerilen yöntemler henüz olgunlaşmamakla birlikte, bilişsel davranış terapisi gibi psikolojik tedavilerden yararlanılabileceği düşünülmektedir (Weinstein, 2014). Bağımlılık ile ilgili alan yazın incelendiğinde 2000'li yıllara kadar internet bağımlılı̆̆ının, bağımlılık olup olmadığı tartışılmakta iken artık günümüzde böyle bir bağımlılığın varlığı kabul edilmekte hatta tedavisi üzerinde durulmaktadır. Öyle ki Ege Üniversitesi’nde "internet bağımlılı̆̆ı” adı altında bir ders açılmış ve Balıklı Rum Hastanesi artık "internet bağımlılarını” tedavi etmeye başlamıştır (Balta ve Horzum, 2008).

Çalışmada, internet bağımlılığı sürecinin incelenmesi ve katılımcılarda farkındalık oluşturulması amaçlarına ilişkin süreçsel drama yaklaşımı benimsenmiştir. Süreçsel drama, çeşitli durum ve oluşumlardan geçerek, yaşantı kaynaklı gelişen ve rol oynama, doğaçlama başta olmak üzere farklı canlandırma teknikleri ile yazma ve konuşma etkinlikleri ile geliştirilen veya sonuçlandırılan bir drama yaklaşımıdır. Adıgüzel (2010, s. 424) yaratıcı drama liderinin, tıpkı diğer tüm eğitimciler gibi, amaçlarına ulaşmada en uygun strateji ve teknikleri seçmesi gerektiğini belirtmektedir.

Süreçsel drama; doğaçlamalardan yararlanarak bir eğitim süreci tasarlamanın bir formudur. Yaratıcı dramanın tüm görünümlerinde olduğu gibi, gerçek hayat öykülerini ve sıklıkla da gerçek nesnelerden yararlanarak, kurgusal bir dünyayı yaratan, bir temsil biçimidir. Bu temsilin ayırt edici yanı, temsil edilecek olayların, katılımcıların müzakereleri ile biçimlenmesidir. Diğer bir deyişle, "süreç", drama katılımcılarının kontrolünde oluşmaktadır. Haseman, (1991, s. 19-20) yukarıdaki açıklamaya ek olarak, ayırt edici özelliklerini şu biçimde özetlemektedir:

a. Katılımcılarda, ele alınan duruma/probleme yönelik sanatsal bir yanıt verme güdüsünü harekete geçirir. 
b. Bir metaksis durumunu kurmayı içerir. Bunun anlamı, "gerçek" ve "kurgusal" dünyanın zihinde aynı anda var olmasıdır. Bu yönüyle, gerçekte kavranan varoluş koşullarının aşılarak, sıradan/verili olanın sorgulanmasına hizmet etmektedir.

c. Yaratıcı dramanın bileşenlerinden yararlanır.

d. Eğitsel bir bağlamda, öğretimin niteliğini sağlamak için, eğitim/sanat etkileşimine yer verir.

e. Öğretici ile öğrenenleri, dramatik olarak oynanabilir eylemler inşa etmek için işbirliğine zorlamaktadır.

f. Süreçseldramada, "drama yapma" konusu katılımcılara dayatılmamakta, onlarla müzakere edilmektedir. Bu müzakereye dayanan yönetim, bir irade beyanı olarak ortaya konmakta, fakat sürecin gözden geçirilmesini, çalışmanın yeni bir doğrultuya doğru gidişini ve araştırma yapmayı engellememektedir.

g. Oyuncu, metin ve seyirci ilişkilerindeki geleneksel ilişkiyi yeniden kurmaktadır. Katılımcılar, oyunu, anında hazırladığı, okuduğu ve değerlendirdiğinden, geleneksel oyuncu, sanatçı ve izleyici rollerini de çökertmektedir.

Süreçsel dramanın yukarıda belirtilen özellikleri, katılımcılara verdiği özerklik, herhangi bir problemi toplumsallaştırarak yeni bir bağlamda değerlendirmeye açması gibi nedenlerle, internet bağımlılı̆̆ını incelemede, elverişli bir araç sunmaktadır.

$\mathrm{Bu}$ çalışmada, süreçsel drama ana yaklaşım olarak belirlenmiş, uzman mantosu yaklaşımı teknik boyutunda ele alınarak uygulama süreci yapılandırılmıştır. Özen'in (2011, s. 43-62) belirttiği noktalar göz önünde tutularak; katılımcılar için öğrenme alanının (internet bağımlılı̆̆ı) bir amaç içinde ele alınması gerekliliği benimsenmiştir. Buradan hareketle de, bir işletme kurulmuş (danışmanlık hizmeti veren bir kurum), katılımcılardan bağımsız bir müşteri kurgulanmış (çocuğu internet bağımlısı olan ve bir bağımlılıkla mücadele merkezi kurmak isteyen bir anne) ve çalışanlara (katılımcılar) yer verilmiştir. Katılımcılar, çalışanlar olarak, bir problem tanımlamakta, diğer bir deyişle, internet bağımlılığı konusunu nesneleştirmektedir. Bu ele alma biçiminin bir diğer katkısı da, katılımcılarda, kısa sürede, "biz" duygusunu oluşturmasıdır. Katılımcılar ve lider, birlikte, hayali bir görevi yerine getirebilmek için çeşitli rolleri denemekte ve bir araştırma sürecini işletmektedir. Genel olarak, süreçsel drama yaklaşımı işe koşularak, internet bağımlısı olan bir çocuğa annesine yardım süreci üzerinden, katılımcıların ilgileri örgütlenmeye çalışılmıştır.

Çalışmanın internet bağımlılı̆̆ı konusundaki farkındalık arttırma amacına, süreçsel drama yaklaşımının sunduğu olanaklarla ulaşılmaya çalışılmıştır. Bu çalışmanın özgün katkısı, internet bağımlılı̆̆ı konusunu süreçsel drama yaklaşımıyla ele alan ilk çalışmalardan biri olmasıdır. Çalışmada, çalışma grubunun istek ve ihtiyaçları göz önünde bulundurularak, etkinlik planlarına son biçimi verilmiştir.

\section{Yöntem}

$\mathrm{Bu}$ bölümde araştırma modeli, örneklem/çalışma grubu, veri toplama araçları, verilerin toplanması ve çözümlenmesi, bulgular ve bulguların değerlendirilmesine yer verilmektedir. 


\section{Araştırmanın Modeli}

Çalışmada, nitel analiz yöntemi benimsenerek, betimleyici bir araştırma yapılmıştır. Buna göre, bir durumun karşılaştırılması, bir hipotezin ispatlanması ya da kontrol grubu ve değişkenler tanımlanmamakta, bir sorunun (internet bağımlılığının) çözümünde süreçsel drama yönteminden yararlanarak, yöntemin etkililiği ve katılımcıların farkındalıklarına yönelik veriler değerlendirilmektedir. Bu anlamda çalışma, eylemsel araştırma (Uzuner, 2005, s. 3) özellikleri göstermektedir. Çalışmanın tasarımı, aşağıdaki adımlarda gerçekleştirilmiştir. Araştırma katılımcılarına yönelik bir soru formu hazırlanarak aşağıdaki sorular sorulmuştur:

1. Yaş grubunuzu göz önünde bulundurunca, size göre, (evrensel olarak) en önemli toplumsal ve kültürel sorunlar nelerdir?

2. Bu sorunları öncelik sırasına koysanız, nasıl bir sıralama yapardınız?

3. Bu sorunlardan hangisini drama ortamında ele almak isterdiniz?

Katılımcılardan gelen yanıtlar doğrultusunda, çalışmanın konusu "internet bağımlılı̆̆ı" olarak belirlenmiştir. İnternet bağımlılı̆̆ına yönelik yapılan okumaların ardından, araştırmacılar tarafından internet bağımlılığının süreçsel drama yöntemiyle işlenmesi gerektiğinde karar kılınmıştır. Konu doğrultusunda, alan yazın taraması yapılmış ve araştırma soruları oluşturulmuştur. Çalışmanın amacı; "internet bağımlılı̆̆ı konusunda farkındalık oluşturmak" olarak belirlenmiştir. Bu genel amaca yönelik olarak aşağıdaki sorulara yanıt aranmıştır:

- İnternet bağımlılı̆̆ nedir?

- İnternet bağımlılı̆̆ının nedenleri nelerdir?

- İnternet bağımlılığı sürecinin bileşenleri nelerdir?

- İnternet bağımlılığın kişiye, aile yaşamına, arkadaşlık ilişkilerine ve eğitim yaşamına olas1 etkileri nelerdir?

- İnternet bağımlılığıyla mücadelede izlenecek yollar nelerdir?

Yukarıda belirtilen sorulara yanıt vermek için, bir araştırma programı oluşturulmuştur. Araştırmanın alanyazın taraması, 04. 02. 2014- 8.12.2014 tarihleri arasında tamamlanmış, ardından çalışma grubunun oluşturulması için katılımc1 adaylarıyla görüşülmüş ve çalışma grubu, 03.12.201411.12.2014 tarihleri arasında gönüllü olarak katılım göstermek isteyen ve çalışma tarihleri konusunda uygun olan kişilerden oluşturulmuştur. Çalışma grubunun oluşturulmasıyla eş zamanlı olarak, (0513.12.2014) çalışma mekânının ve araç-gereçlerin sağlanması tamamlanmıştır. Atölyelere ilişkin içeriğin belirlenmesi yaklaşık iki aylık bir sürece yayılmıştır ( 18.09. 2014- 12-11. 2014). Atölye planlarının son hallerinin belirlenmesi ve gözden geçirilmesi bir ayda tamamlanmıştır (12.11. 201412.12.2014). Atölyeler, 13.12.2014- 17.12. 2014 tarihleri arasında yürütülmüştür.

\section{Çalışma Grubu}

Çalışmanın çalışma grubu 19 kişiden oluşmuştur. 16 katılımcı Gümüşhane Üniversitesi ‘nin farklı bölümlerinde(sağlıkyönetimi, gıda mühendisliği, halklailişkiler ve tanıtım, inşaat mühendisliği) öğrenimlerini sürdüren lisans düzeyindeki öğrencilerden, üç katılımcı ise lisans üstü öğrencilerinden (iletişim fakültesi) oluşmuştur. Çalışma grubu yapılan duyuruya gönüllü olarak katılan katılımcılarla oluşturulmuştur. 


\section{Veri Toplama Araçları}

Çalışmayı değerlendirmek için kullanılan veri toplama araçlarına aşağıda yer verilmiştir.

a) Ön test- son test: Katılımcıların drama çalışmaları öncesinde internet bağımlılığına ilişkin bilgilerini yoklamak amacıyla açık uçlu sorulardan oluşan bir ön test, çalışmanın sonunda da aynı soruların sorulduğu bir son test uygulanmış ve arada fark olup olmadığına bakılmıştır. Katılımcılara yöneltilen sorular aşağıdaki gibidir:

- İnternet bağımlılığı nedir?

- İnternet bağımlılı̆̆ının nedenleri nelerdir?

- Bağımlılık süreci nasıl gelişir?

- İnternet bağımlılığın kişiye, aile yaşamına, arkadaşlık ilişkilerine ve eğitim yaşamına etkileri nelerdir?

- İnternet bağımlılığıyla mücadelede hangi alternatif yollar izlenebilir?

b)Katılımcıların çalışma boyunca ürettikleri, mektup, gazete, afişler, atölye değerlendirme yazıları gibi materyaller betimsel analiz yoluyla incelenmiştir. Süreçsel drama atölyelerinin tümü kamera kaydına alınmış, çalışmalar süresince katılımcıların iznine bağlı olarak, fotoğraf çekimi yapılmıştır.

\section{Verilerin Toplanması ve Verilerin Çözümlenmesi}

Bulgu toplama araçları olarak; katılımcıların yazılı, sözlü ifadeleri ile süreç içinde ürettikleri materyaller ve liderin gözlemlerinden yararlanılmıştır. İlk iki oturumun tamamı kamera kaydına alındığından, bulguların yorumlanmasında bu kayıtlara başvurulmuştur. Bulguların yorumlanmasında betimsel analize başvurulmuştur. Çalışma süresince toplanan yazılı ve görüntülü dökümanlar, tematik bir analize tabi tutulmuştur. Buna göre, öntest ve son testten elde edilen yazılı yanıtlardan en sık tekrarlanan temalar belirlenmiş, bu temaların yinelenmeleri sıklık ve yüzde olarak tablolaştırılmıştır. Çalışmada elde edilen diğer veriler, katılımcıların internet bağımlılığına ilişkin görüşleri, liderin rollerine ilişkin görüşleri ile roller ve çalışmanın geneli başlıklarında toplanarak analiz edilmiştir.

\section{Bulgular}

Bu bölümde çalışmanın bulguları ve bulguların yorumlanmasına yer verilmektedir. Bulgular üç başlıkta incelenmektedir: a)İnternet Bağımlılığı, b) Süreçte katılımcının liderin rolleriyle ilgili görüşleri ve c) Roller ve çalışmanın geneli.

\section{a) İnternet Bağımlılı̆̆ı}

Çalışmanın ön test ve son testinin uygulanmasının ardından gelen yazılı yanıtlar aşağıda değerlendirilmiştir. Tablo 1'de süreç değerlendirmesinde ön test ve son teste yapılan içerik analizine yer verilmektedir. Katılımcıların sorulara yanıtlarında ortak olarak yinelenen kavramlar, temalar halinde örgütlenmiş, yinelenen temaların sıklık ve yüzdeleri belirtilmiştir. 
Tablo 1. Ön test - Son test Sorularının Değerlendirilmesi

\begin{tabular}{|c|c|c|c|c|}
\hline Soru & Yanitlar & Tema & Sıklık & Yüzde \\
\hline $\begin{array}{l}\text { Internet } \\
\text { bă̆ımlılı̆̆ı̆a } \\
\text { ilişkin görüşleri }\end{array}$ & $\begin{array}{l}\text { Sürekli internete bağlanma isteği duymak, eksiklik } \\
\text { hissetmek, normalden fazla süre bilgisayar başında } \\
\text { zaman geçirmesi, arzu ve ihtiyaç hissetmek, genç } \\
\text { nüfusta görülmesi, alışkanlıktan daha öteye giderek } \\
\text { bağımlılığa dönüşmesi, isteğin önüne geçilememesi }\end{array}$ & $\begin{array}{l}\text { Mutluluk } \\
\text { ve takıntı }\end{array}$ & 12 & 63 \\
\hline $\begin{array}{l}\text { Internet } \\
\text { bă̆ımlılı̆̆ının } \\
\text { nedenlerine ilişkin } \\
\text { görüşleri: }\end{array}$ & $\begin{array}{l}\text { Yaşam sevinci teması, aile içi ve arkadaş ilişkilerindeki } \\
\text { yakınlığın azalması, ailenin ilgisizliği, eğitim } \\
\text { düşüklüğü, kendinden daha güçlü biri olabilme imkanı } \\
\text { sunması, özgüven eksikliği, karamsarlık, yalnızlık, } \\
\text { şehirleşme (kentleşme)- oyun alanlarının azalması, } \\
\text { güven problemi, medyanın rolü, internete erişimin } \\
\text { kolaylaşması, bilgisayarın bir arkadaş haline gelmesi, } \\
\text { kazaların sonuçları (ön metne gönderme yapılıyor- } \\
\text { HS notu), depresyon, stres, aile içi şiddet, anne- baba } \\
\text { ilişkisinin kötü olması, sosyal yalıtıma maruz kalmak, } \\
\text { oyundan alınan haz, fiziki yetersizlikler. }\end{array}$ & $\begin{array}{l}\text { Aile } \\
\text { ilişkileri }\end{array}$ & 15 & 78 \\
\hline $\begin{array}{l}\text { Internet } \\
\text { bağımlılığııın } \\
\text { etkilerine ilişkin } \\
\text { görüşleri: }\end{array}$ & $\begin{array}{l}\text { Asosyallik,dışlanma, eğitimdeki başarısızlık, } \\
\text { izolasyon, başarısızlık, sağlık sorunları (kilo alma), her } \\
\text { zaman olumsuz yönleri üzerinde durmamak gerekir., } \\
\text { kişilik bozukluğu, depresyon, aile içi anlaşmazlıklar, } \\
\text { aile bağlarının zayıflaması }\end{array}$ & İzolasyon & 18 & 94 \\
\hline $\begin{array}{l}\text { Internet } \\
\text { bağımlılı̆̆l } \\
\text { sürecinin } \\
\text { bileşenlerine } \\
\text { ilişkin görüşleri: }\end{array}$ & $\begin{array}{l}\text { Bireyin yalnızlaşması/dışlanması- tatminsizlik } \\
\text { hissi- internetle tanışması- sanal gerçeklikten tatmin } \\
\text { sağlama- sanal gerçeklikten kopamama }\end{array}$ & Gerçeklik & 19 & 100 \\
\hline $\begin{array}{l}\text { Internet } \\
\text { bağımlılı̆̆lyla } \\
\text { mücadeleye ilişkin } \\
\text { görüşleri: }\end{array}$ & $\begin{array}{l}\text { Sosyalleşme, farklı hobiler oluşturma, ebeveyn } \\
\text { eğitimi, hastalığın kabul edilmesi, başkalarıyla } \\
\text { kıyaslama yapıımaması gerekir, arkadaş ortamı, } \\
\text { sınırlamalar, internet bağımlılığı tedavi gerektirmez- } \\
\text { farkındalıkla aşılır, sosyal destek (aile, arkadaşlar). } \\
\text { Öncelikle, bağımlı olduğunu kabul etmeli. }\end{array}$ & $\begin{array}{l}\text { Sosyal } \\
\text { destek }\end{array}$ & 19 & 100 \\
\hline
\end{tabular}

Tablo 1'de katılımcıların üçüncü oturumda, değerlendirmeye yönelik yazılı ifadeleri gösterilmektedir. Bu ifadelerde, çalışmaların başında ifade edilen görüşlerden farklı olarak, çalışma bitiminde ulaştıkları yeni sonuçlara yer verilmektedir. Katılımcıların 12'si (\%63) bireyin mutlu olmak için interneti sürekli ve takıntılı biçimde kullanmaları, durumunu ifade etmiştir. Bu yaklaşım, ilgili yazında, (Ferraro vd., 2007) internet bağımlılı̆̆ını boşluk duygusundan kurtulmak ve bireysel 
mutluluk arayışıyla ilişkilendirme ile koşutluk göstermektedir. Öte yandan, öne çıkan ifadelerden biri de, genç kuşak da ortaya çıkan bir bağımlılık türü olmasıdır. Bunun birçok nedeni olmakla birlikte, çoğunlukla, bu durum, çağın bir gereği, gençlerden istenen yetkinliklerin bir parçası olarak değerlendirilmektedir. Yazında (Nalwa ve Anand, 2003), bu duruma işaret edildiği görülmektedir.

Katılımcıların internet bağımlılı̆̆ına ilişkin görüşleri ise daha çok kişiden kaynaklanan nedenler olarak öne çıkmaktadır. Yazında (Balcı ve Gülnar, 2009; Batıgün ve Kılıç, 2011), internet bağımlılı̆̆ının neden sonuç ilişkisi karmaşık olarak nitelendirilmektedir. Buradan hareketle de bağımlılığın nedenlerini tespit etmek kimi zaman güç görünmektedir. Örneğin, internet bağımlığ mı depresyona ve mutsuzluğa yol açmaktadır, yoksa tersi mi olmaktadır? sorusunu yanıtlamak kolay görünmemektedir. Süreçsel dramada ele alınan kahraman, fiziksel yetersizliklerinden dolayı internet bağımlılı̆̆ına yatkın olarak görülmüştür. Bunun yanında, mikro analiz boyutunda; aile içi anlaşmazlıklar, ilgisizlik, sosyal desteğin az oluşu da internet bağımlığına neden olabilmektedir. Katılımcıların, sürecin de etkisiyle, ailenin internet bağımlılı̆̆ını yordayacağına ilişkin görüşleri (15 kişi, \%78) oluşmuştur. Bu durum, ilgili yazınla uyumlu görünmektedir (Esen ve Siyez, 2011). İncelenen yazında fazla vurgulanmayan, makro boyutta ise, sözgelimi, plansız kentleşmenin bir sonucu olarak çocuklara ve gençlere ayrılan oyun alanlarının, diğer kesimler için kamusal alanların yok olması interneti yeni bir tür sosyalleşme alanı haline getirmektedir. Bu alanda, özellikle başka türlü bir benlik sunumuna imkan verilmekte; kişiler, gerçek yaşamda sağlayamadıkları oyun, heyecan, gerilim duygularını daha fazla deneyimleme imkanı bulabilmektedir.

Çalışmada, ikinci oturum ağırlıklı olarak internet bağımlılı̆̆ının etkilerine ayrılmıştır. İnternet bağımlılığı, diğer bağımlılık türlerinde olduğu gibi, fiziksel, sosyal ve psikolojik etkileri bulunmaktadır. Katılımcılar çoğunlukla, internet bağımlılığının sosyal etkilerine değinmiştir. Fiziksel etkilerle ilgili en belirgin vurgu ise, kişinin bilgisayar başında yemek yemesi ve hareketsizliğinden kaynaklanan kilo alma problemine yapılmıştır. Sosyal etkiler, aile ve arkadaş ilişkilerinde gerileme, kişinin izolasyonu (18 kişi, \%94) ve başarısızlık olarak görülmektedir. Bu görüşler, yazınla uyum göstermektedir (Balc1 ve Gülnar, 2009).

İnternet bağımlılı̆̆1 sürecinin bileşenleri, aşama aşama değerlendirildiğinde, katılımcılar, internetle tanışma aşamasından, internete bağlanma aşamasına kadar geçen süreci, "gerçeklik" (19 kişi, \%100) üzerinden tanımlamışlardır. Buna göre, kişi, gündelik hayattaki gerçeklikten vazgeçerek, sanal gerçeklikte tatmin sağlama yoluna gitmekte, gerçeklik duygusunu yitirmekte ve bir fasit daire biçimindeki bağımlılık döngüsüne kapılmaktadır.

İnternet bağımlılığıyla mücadele, diğer bağımlılık türleriyle mücadeleye benzer biçimde yürütülmektedir. Katılımcılar internet bağımlılığıyla mücadelenin kişiye farkındalık/özbilinç kazandırılmasıyla sağlanabileceğini belirtmektedir. Bunun yanında, sosyal destek en belirgin destekleyici unsur olarak öne çıkmaktadır (19 kişi, \%100). Yazında da bu konuda henüz bir netlik bulunmamaktadır. Bu anlamda, çalışmanin, süreçsel drama yoluyla, diğer bir deyişle, eğitim yoluyla internet bağımlılığına yönelik farkındalık yaratacağını ve bağımlılığa ilişkin tutum değişikliğine katkıda bulunacağı umulmaktadır.

\section{b) Süreçte Katılımcıların Liderin Rollerine İlişkin Görüşleri}

Yaratıcı drama çalışmalarının değerlendirilmesinde, değerlendirmenin niteliği yaratıcı dramanın amaçları ve bu doğrultuda işlenen aşamalar belirlemektedir. Değerlendirmede, liderin ve katılımcıların kendilerini değerlendirmeleri esas alınmaktadır (Adıgüzel, 2010, s. 257). 
Yazılı ve görsel materyaller değerlendirildiğinde, üzerinde durulması gereken bir konunun "öğretmen rolde" yaklaşımı olduğu görüldü. Çalışmalarda, lider, sırasıyla, "Başkan”, "Asistan”, "İnternet bağımlılığı uzmanı" ve "Baba” rollerine girmiştir. Çalışmanin başlangıç oturumunda, katılımcılara doğrudan bir rolle yaklaşılmıştır. Bu rol, tam olarak belirli olmayan bir kurumun yöneticiliği rolüdür. Bu rol aracılığıyla katılımcılara yaklaşılarak, hepsinin birer kurum çalışanı oldukları, bu kurumun bir tür danışmanlık firması olduğu, hepsinin belirli işe seçim aşamalarından geçerek kuruma katıldıkları söylenmiştir. Sonrasında, katılımcılara ön metin okunmuş ve çalışmaya katılıp katılmayacakları sorulmuştur. Bu, Heathcote yaklaşımında vurgulanan bir önermedir. Katılımcıların çalışmanın amacına yönelik olarak harekete geçirilmesini sağlamaktadır. Katılımcılar, çalışmanın ilk birkaç dakikası içinde bu role "Başkan" ya da "Başkanım" diye hitap etmeye başlamışlardır. Lider kendisiyle söz konusu rolü farklılaştırmak için sesini ve bedenini daha yaşlı ve otoriter biçimde kullanmaya gayret etmiştir. Bu rol, Adıgüzel'in (2010, s. 443) tarif ettiği diktatör tarzı liderlikle benzerlikler taşımaktadır(Örneğin: Çalışma sonrasında değerlendirmeye yönelik hazırlanan gazetelerde, liderlik konusuna da değinilmiş ve “ ...Başkan mı, Hoca mı? .....ara ara girdiği başkan karakteriyle herkesin kafasını karıştırdı. Başkan ile kendi rolü arasında ses değişikliği olan lider, başkan rolüyle gayet agresif bir kişiliğe sahipti...”denmiştir).

Hızlı ve etkili olmakla birlikte, drama yaşantısı sınırlı olan katılımcılara uygulanacak teknikleri ve temel drama prensiplerini anlatmada kısıtlı kalmaktadır. Bu nedenle, otokratik bir yaklaşımla sürdürdüğü rolünü belirli bir sınırda tutmak ve işlevsel kılmak amacıyla, "asistan" rolüne girilmiştir. Asistan rolü daha yalın bir oyunculuğa dayanmakta ve katılımcılar ile (kurum çalışanları) başkan arasında bir köprü kurarak çalışmaların özellikle de biçimsel işleyişini sağlamaya yardımcı olmuştur. Başkan rolü ise, kurumun anneyle olan iletişimini sağlayan bir konumda tutulmuştur. Özetle, başkan rolü, metaksise hizmet ederek, katılımcıları çalışanlar rolünde tutmuştur. Bu konumdan çocuğa yardım etmek daha kolay olmuştur. Çünkü amaçları anneye yardım aracılığıyla aslında çocuğa yardım etmektir. Asistan rolü de, başkan (işveren-yönetici) ve katılımcılar arasındaki gerilimi azaltan ve katılımcıların doğaçlamalara hazırlıklarını kolaylaştıran bir konuma sahip olmuştur.

Katılımcıların Lider Rollerine İlişkin Görüşleri

A: Başkanın egoist olduğunu düşünüyordum, meğerse onun rolü buymuş...

F: Başkan rolü her şeyin sırasıyla oluşmasını sağladı....

H: .... “Neden bu çalışmay yapıyoruz?”.... “ Amacımız tam olarak nedir?” Direk role girerek başlamamız sebebi ile de belki de bunlar havada kaldı....

Liderin girdiği diğer bir rol ise, kısa bir süre için yararlanılan "internet bağımlılı̆̆ı uzmanı" rolüdür. Burada, katılımcılarla röportaj tekniği üzerinden diyalog kurulmuştur. Liderin bu rolü tercih etmesi, biraz da zorunluluktan doğmuştur. Şöyle ki, katılımcılar konuya uzaktır ve çalışmanın iç tutarlılığını bozmamak için onlara didaktik bir metin sunulmaması gerektiği kararına varılmıştır. Bu nedenle, asistan rolünü andırır olan ama kıyafetlerde yapılan birkaç değişiklikle (yüzük, gözlük, kazakta yapılan değişikliler )internet bağımlılığına ilişkin bilimsel bilgilerin sunulmasına hizmet etmiştir. Son girilen rol ise doğaçlamaları ön metne ve çalışmanın amaçlarına bağlamak için kısa süreliğine girilen ana kahramanın (Deniz) babası rolüdür. Anneyi zorlayarak, internet bağımlılığ merkezi kurma girişimini tekrar katılımcıların gündemine sokmuştur. 


\section{c) Roller ve Çalışmanın Geneli}

$\mathrm{Bu}$ bölümde katılımcıların sözlü ifadeleri, gazete çalışması ve hazırladıkları diğer materyallerden elde edilen değerlendirmeye yer verilmektedir.

Yapılan gazete çalışmasından iki haber çalışmada ele alınan rollere ve çalışmanın geneline ilişkin ayırt edici bilgiler sunmaktadır.

Birincisi: “.....gazetemize konuşan Meltem Hanım, "bu sayede sadece oğlum Deniz değil, bütün bağımlıların tedavi edileceğine inanıyorum. ......3 yıldır bu hastalıkla mücadele ediyoruz ama şimdi umudum arttı" dedi.Yaklaşık 5 milyon insanın yakalandığı bu hastalık herkesi korkutmuştu ana şimdi internet bă̆ımlılı̆̆ılla mücadele ekipleri bu korkunun üstesinden gelecek. ...”.

İkincisi: ‘ Sağlık Meslek Yüksekokulu öğrencilerinin katıldĭ̆ı drama ĕgitimi iki gün sürdü. Ĕ̈itim süresince internet bağımlılı̆̆ının etkileri ve nasıl mücadele edilmesi gerektiği ile ilgili çalışmalar yapıldı. 26 (sayı yanlış belirtilmiş- HS notu) öğrencinin katıldı̆̆ e ĕitimler sonrası değerlendirme toplantısı yapılarak, teşekkür belgesi takdim edildi. ...”.

Değerlendirme oturumunda yapılan değerlendirmeler, genel olarak çalışmanın farkındalıkları yükselttiği yönünde olmuştur. Örneğin, katılımc1lardan biri: “...Ititiraf ediyorum. Ben bir internet bağımlısı olduğumu bu çalışmalar sayesinde fark ettim ... ” demiştir. Bunun yanında, süreçseldramanın biçimsel olarak yeni bir yaklaşım sunması ve dramatik gerilimi canlı tutması bakımlarından değer gördüğü söylenebilir. Çalışma değerlendirmesine ilişkin son nokta ise rollerin değerlendirilmesi noktasında olmuştur.

Çalışmanın bir diğer bulgusu ise, katılımcıların internet bağımlılı̆̆ının ele alınışında yararlanılan kahramanlara eleştirel yaklaştıklarını göstermektedir. $\mathrm{Bu}$ noktada, kahramanların kimler olduğu ve dramatik kurguya nasıl hizmet ettiklerini belirtmek gerekmektedir. Katılımcılar, duvardaki rol ve önceki çalışmalardaki bilgilerini kullanarak, ana kahramanları adlandırmış ve onların özelliklerini incelemiştir. Ana kahraman, internet bağımlısı olan Deniz'dir. Deniz'in annesi, kurumumuzdan yardım isteyen kişi ise Meltem Hanım'dır. Babası ise, Mahmut Bey'dir. Çalışmalarda daha çok Deniz'in ev içi ve okul yaşantısı ele alınmıştır. Katılımcılardan biri, konuya daha iyi odaklanmak için ana kahraman üzerinde durmak gerektiğini belirtmektedir: “.....Kardeş rolü kesinlikle gereksizdi... Anne, baba ve çocuk etrafinda incelendi............ sürece ana kahramanın değil de diğer kahramanların rollerinden yaklaşmak konuyu anlamak açısından daha faydalı olmaktadır....".

\section{Sonuç ve Öneriler}

Yapılan etkinliklerde; internet bağımlılığ sürecinin incelenmesi, internet bağımlılı̆̆ kavramının internet bağımlılığının nedenlerinin, bağımlılık sürecinin bileşenlerinin, internet bağımlılı̆̆ın kişiye, aile yaşamına, arkadaşlık ilişkilerine ve eğitim hayatına olası etkilerinin bilinmesi ve İnternet bağımlılığıyla mücadelede izlenecek yolların belirlenmesine çalışılmıştır. Projenin bulguları göz önünde tutulduğunda iki başlıkta da sonuca vardığı görülmüştür. Birinci sonuç, çalışmanın birincil amacına yönelen, internet bağımlılığına yönelik farkındalığın oluşturulması ya da arttırılmasıdır. Bu temel amaca ulaşmak için; internet bağımlılığının nedenleri, oluşumu, etkileri ve mücadele yöntemleri üzerine katılımcıların bilgi ve yaşantılarının ilerletilmesine çalışılmıştır. Gerek katılımcıların ifadeleri ve yarattığı ürünler, gerekse liderin gözlemleri bu konuda bir başarı sağlandığını göstermektedir. Katılımcılar için, internet bağımlılığı bir gündem haline gelmiştir. 
Yukarıdaki genel amaca ek olarak, projede yaklaşım açısından süreçsel dramanın uygulanabilirliğine ilişkin bazı sonuçlara ulaşılmıştır. İnternet bağımlılığı konusuna süreçsel drama yaklaşımı ile eğilen ilk çalışmalardan olan bu çalışmada, iyi planlanırsa, süreçsel drama yaklaşımının internet bağımlılığı konusunda farkındalık yaratma açısından belirgin biçimde elverişli olduğu görülmüştür. Liderin rolde olması, uzman yaklaşımı, komisyon kurma gibi projede doğrudan ya da dolaylı olarak ele alınan yaklaşım ve teknikler, hem bilimsel hem de dramatik bilgi açısından önemli bir potansiyel taşımaktadır. Bu anlamda, süreçsel drama yaklaşımının uygulanmasında izlenecek yola ilişkin bir katkı yapıldığı umulmaktadır.

Sürecin farklı yaş, eğitim durumu ve mesleklerden gelen (genel olarak farklı demografik kompozisyon) katılımcılarla tekrarlanarak bir karşılaştırma şansı sağlanmasının yararlı olabileceği düşünülmektedir. Bunun dışında, projenin uygulanmasında;

- Süreçsel drama konusunda deneyimli bir liderin bulunmasının,

- Ön metnin grupla birlikte oluşturulmasının,

- Proje oturumlarının hazırlanmasının ardından uzman kişilere başvurularak katkı sağlanmasının,

- Oturumlara (uzman rolünde) alan uzmanlarının çağırılmasının

- Projenin değerlendirilmesi aşamasında veri toplama ile bulguların analizi konusunda tam bir netlik sağlanmasının benzer bir yaklaşımla projelerini tasarlayacak lider adaylarına katkı sağlayacağ1 görülmektedir.

\section{Kaynakça}

Adıgüzel, H. Ö. (2014). Eğitimde yaratıcı drama, (5. Baskı), Ankara: Naturel Yayınevi.

Arısoy Ö. (2009). Internet addiction and itstreatment. Current Approaches in Psychiatry, 1 (1) (2009), 55-67.

Ayas T., Çakır Ö ve Horzum M.B. (2011). Ergenler için bilgisayar bağimliliği ölçeği. Kastamonu Eğitim Dergisi 19 (2), 439-448.

Balcı, Ş. ve Gülnar, B. (2009). Üniversite öğrencileri arasında internet bağımlılığı ve internet bağımlılarının profili. Selçuk Illetişim, 6 (1), s. 5-22.

Balta, Ö. Ç. ve Horzum M. B. (2008). The factos that affect internet addiction of students in a web based learning environment. Ankara University Journal of Faculty of Educational Sciences, 41 (1), 187- 205.

Batıgün, N. Kılıç. (2011). İnternet bağımlılı̆̆ ile kişilik özellikleri, sosyal destek psikolojik belirtiler ve bazı sosyo-demografik değiş̧enler arasındaki ilişkiler. Türk Psikoloji Dergisi, 26, 1-10.

Çardak, M. (2013). Psychological well-being wnd internet addiction among university students. TOJET: The Turkish Online Journal of EducationalTechnology, 12 (3), 134-141.

Cengizhan, C. (2005). Öğrencilerin internet ve bilgisayar kullanımında yeni bir boyut: internet bağımlılı̆̆ı. M.Ü. Atatürk Ĕgitim Fakültesi Eğitim Bilimleri Dergisi, 22, 83-98.

Csikszentmihalyi, M. (2005). Aklş: Üst düzey yaşantının psikolojisi. (S. Kunt Akbaş, Çev.). Ankara: HYB.

Çakır Ö., Ayas T. ve Horzum M.B. (2011). An investigation of universitystudents' internet and gameaddictionwithrespect to severalvariables. Ankara University, Journal of Faculty of Educational Sciences, 44 (20), 97-115.

Çakır-Balta, Ö. \&Horzum, M.B. (2008). The factorsthataffect internet addiction of students in a web basedlearningenvironment. Ankara University Journal of Faculty of Educational Science, 41(1), 187-205. 
Ekinci, A. (2002). Aziz Antonius'un baştan çıkarılması: Bir kötü alışkanlık olarak Internet (Enticing Saint Antonius: Internet as an abusingaddiction). Cogito Dergisi, 30, 227-235.

Esen, E. ve Siyez, D. M. (2011). Ergenlerde internet bağımlılığını yordayan psiko-sosyal değişkenlerin incelenmesi. Türk Psikolojik Danışma ve Rehberlik Dergisi, 4, 127-138.

Ferraro, B. C., A. D’Amico, M. Di Blasi (2007). Internet addictiondisorder: An Italian study. Cyberpsychology and Behavior, 10 (2) (2007), pp. 170-175

Griffiths, M. (2000) Does internet and computer "addiction" exist? Somecasestudy evidence. Cyberpsychology and Behavior, 3 (2000), 211-218.

Günüç, S. ve Kayri, M. (2010). Türkiye'de internet bağımlılık profili ve internet bağımlılık ölçeğinin geliştirilmesi: geçerlik-güvenirlik çalışması. Hacettepe Üniversitesi Eğitim Fakültesi Dergisi, 39, 220 232.

Hazar, M. (2011). Sosyal medya bağımlılığı- Bir alan çalışması. Illetişim Kuram ve Araştırma Dergisi, (32),151176.

Haseman, Bradley C. (1991). Improvisation, process drama and dramaticart. The Drama Magazine, 19-21.

Heap, B. ve Simpson A. (2004). Aids education in the common wealth Carıbbean Caribbean Quarterly, 50(19 1, HIV (March 2004), pp. 83-98.

Nalwa, K. ve Anand P. W. (2003). Internet addiction in students: a cause of concern. Cyber Psychology\&Behavior. December 2003, 6(6): 653-656.

Özen, Z., (2011), Dorothy Heathcote 'un yaratıcı drama yaklaşımları, Yayımlanmamış yüksek lisans tezi, Ankara Üniversitesi Eğitim Bilimleri Enstitüsü, Ankara.

Seligman, M.E.P. (2007). Gerçek mutluluk. Kalıcı doyum potansiyelinizi gelişsirmek için yeni olumlu psikolojinin kulllanilması. Ankara: HYB.

Shek, D T L,Yu L (2012). Internet addiction phenomenon in early adolescents in Hong Kong. The Scientific World Journal, 1-9.

Şimşek, E. \& Balaban-Sal1, J. (2014). The role of Internet addiction and social media membership on university students' psychological capital. Contemporay Educatonal Technology, 5(3), 239-256.

Young, K. S. (1996, August). Internet addiction: The emergence of a newclinicaldisorder. Paper presented at the 104th annual meeting of the American Psychological Association, Toronto, Canada.

Weinstein, A, Feder LC, Rosenberg KP, Dannon P. (2014). Internet addiction disorder: overviewand controversities. In: Rosenberg KP, Feder LC (Eds.), Behavioral Addictions, Philadelphia: Academic Press, pp. $99-118$

White, M. (2011). Internet addiction: a review of associated health hazards, http://www.myhealthyhome.com/ wp-content/uploads/2011/02/Tech-Invasion-Internet-Addiction.pdf.

Uzuner, Y. (2005) Özel eğitimden örneklerle eylem araştırmaları. Ankara Üniversitesi Eğitim Bilimleri Fakültesi Özel Ĕgitim Dergisi, 6 (2) 1-12. 